\title{
Chalcopyrite Dissolution in Acidified Ferric sulfate: a Thermodynamic Study of Intermediate Phases
}

\author{
Kolela J Nyembwe, Elvis Fosso-Kankeu*, Frans Waanders and Martin Mkandawire
}

\begin{abstract}
The leaching of chalcopyrite $\left(\mathrm{CuFeS}_{2}\right)$ is characterized by slow $\mathrm{Cu}$ dissolution rate and poor recoveries, mainly at atmospheric pressure and low temperature. It is believed that, the parabolic rate is caused by the solid-state transformation that takes place during mineral dissolution which leads to the formation of a dissolution barrier that prevents further $\mathrm{Cu}$ removal from $\mathrm{CuFeS}_{2}$. In this study, the dissolution of copper from $\mathrm{CuFeS}_{2}$ mineral was investigated in acidified ferric sulfate at atmospheric pressure. The results revealed that only $22 \% \mathrm{Cu}$ were recovered after 5 hours at $50^{\circ} \mathrm{C}$ at a solution $\mathrm{pH}$ of 1.8. It was observed that, the dissolution of $\mathrm{Cu}$ was accompanied by intermediate phases formation which seem to have a retarding effect on the direct oxidation of $\mathrm{CuFeS}_{2}$. The transient metastable phases were Copper sulphides rich minerals including bornite $\left(\mathrm{Cu}_{5} \mathrm{FeS}_{4}\right)$, chalcocite $\left(\mathrm{Cu}_{2} \mathrm{~S}\right)$ and covellite $(\mathrm{CuS})$. Thermodynamic predictions revealed that $\mathrm{Cu}_{5} \mathrm{FeS}_{4}$ and $\mathrm{Cu}_{2} \mathrm{~S}$ were the soluble intermediates and were characterized by a slow dissolution rate. Whereas, $\mathrm{CuS}$ has been identified as a refractory intermediate inhibiting $\mathrm{Cu}$ dissolution. The dissolution phase diagram was obtained and further discussed with regard to the intermediate phase formation, evolution, transformation and dissolution.
\end{abstract}

Key words - chalcopyrite, dissolution, ferric sulfate, solid state diagram

\section{INTRODUCTION}

Efficient leaching of chalcopyrite concentrates at ambient pressure remains a challenge because of the slow dissolution kinetics of this mineral in most leaching media [1,2]. The slow and incomplete dissolution is attributed to the formation of a passive layer on the mineral surface regardless of the method used whether chemical or bioleaching [3-7]. The nature and composition of this barrier, remain subject to controversy up-to-date [8-10]. The most often suggested candidates to form

Kolela $\mathbf{J}$ Nyembwe is with Water Pollution Monitoring and Remediation Initiatives Research Group, School of Chemical and Minerals Engineering, Faculty of Engineering, North-West University, South Africa.

Elvis Fosso-kankeu is with Water Pollution Monitoring and Remediation Initiatives Research Group, School of Chemical and Minerals Engineering, Faculty of Engineering, North-West University, South Africa.

Frans Waanders is with Water Pollution Monitoring and Remediation Initiatives Research Group, School of Chemical and Minerals Engineering, Faculty of Engineering, North-West University, South Africa.

Martin Mkandawire is with Department of Chemistry, School of Science and Technology, Cape Breton University, Canada. the passivating layers are metal-deficient phases, elemental sulphur and jarosite [11]. In order to enhance the $\mathrm{Cu}$ dissolution from the $\mathrm{CuFeS}_{2}$ mineral, different methods and techniques have been proposed from various laboratory studies. These methods include the use of sulfate-chloride solutions, microorganisms, fine/ ultra-grinding and silver ions addition [12].

During mineral dissolution, both the $\mathrm{pH}$ and potential (Eh) are the major chemical factors that control the leaching mechanism (kinetic or equilibrium), availability for leaching, complexation, and sorption processes. However, it was reported that the media $\mathrm{pH}$ has a minimal response on the $\mathrm{CuFeS}_{2}$ dissolution rate in acidified ferric sulfate and had to be maintained low in order to avoid iron (Fe) hydrolysis and/ or hydroxy precipitates formation [13-16]. It was Cordoba et al., [17] who identified that high $\mathrm{Cu}$ recoveries were achieved at acidic $\mathrm{pH}$ values in the range of 1.5 - 2. The existence of narrow potential Eh zone in which the dissolution rate and recovery are optimal was identified to lie between $400-450 \mathrm{mV} / \mathrm{Ag} / \mathrm{AgCl}$ [18-21].

Both $\mathrm{pH}$ and Eh are well summarized on the pourbaix (Eh-pH) diagram, it serves as initial identification for eventual dissolution reactions under both oxidizing and reducing environment at different $\mathrm{pH}$ values. From the diagram, the increase in potential value on the surface of the dissolving mineral leads to the occurrence of different oxidation reactions which favor the formation of intermediates phases. These transitory phases include the formation of bornite $\left(\mathrm{Cu}_{5} \mathrm{FeS}_{4}\right.$ $\mathrm{Eq}(2))$, chalcocite $\left(\mathrm{Cu}_{2} \mathrm{~S} \mathrm{Eq(3))}\right.$ and covellite $(\mathrm{CuS} \mathrm{Eq(4))}$ all of which are successfully dissolved at potential above $0.5 \mathrm{~V}$ at $\mathrm{pH}$ values ranging from 0 to 2 .

$$
\begin{aligned}
& \mathrm{Eq} \text { (1): } \mathrm{CuFeS}_{2}+2 \mathrm{Fe}_{2}\left(\mathrm{SO}_{4}\right)_{3}=\mathrm{CuSO}_{4}+5 \mathrm{FeSO}_{4}+2 \mathrm{~S}^{\mathrm{o}} \\
& \Delta \mathrm{G}=-16.3\left(\mathrm{kCalmol}^{-1}\right) \\
& \mathrm{Eq}(2): 5 \mathrm{CuFeS}_{2}+4 \mathrm{Fe}_{2}\left(\mathrm{SO}_{4}\right)_{3} \rightleftharpoons \mathrm{Cu}_{5} \mathrm{FeS}_{4}+12 \mathrm{FeSO}_{4}+6 \mathrm{~S}^{\mathrm{o}} \\
& \Delta \mathrm{G}=-68.7\left(\mathrm{kCalmol}^{-1}\right) \\
& \mathrm{Eq}(3): 2 \mathrm{CuFeS}_{2}+2 \mathrm{Fe}_{2}\left(\mathrm{SO}_{4}\right)_{3} \rightleftharpoons \mathrm{Cu}_{2} \mathrm{~S}+6 \mathrm{FeSO}_{4}+3 \mathrm{~S}^{\mathrm{o}} \\
& \Delta \mathrm{G}=-30.8\left(\mathrm{kCalmol}^{-1}\right) \\
& \mathrm{Eq} \text { (4): } \mathrm{CuFeS}_{2}+\mathrm{Fe}_{2}\left(\mathrm{SO}_{4}\right)_{3} \rightleftharpoons \mathrm{CuS}+3 \mathrm{FeSO}_{4}+\mathrm{S}^{\mathrm{o}} \\
& \Delta \mathrm{G}=-18.6\left(\mathrm{kCalmol}^{-1}\right)
\end{aligned}
$$

The issue rising with the direct application of the Eh-pH diagram to sulfide leaching is the formation of various intermediate. These phases may to some extent slow the chemical kinetics associated with the $\mathrm{Cu}$ dissolution from 
$\mathrm{CuFeS}_{2}$ and it is difficult to predict the presence of intermediates from thermodynamics only. It is, therefore, appropriate to review the kinetic aspect of the dissolution in order to obtain a better understanding. To that, the formation and evolution of the transition phases could help explain the leaching process.

The aim of the present investigation is to (1) study $\mathrm{Cu}$ dissolution from $\mathrm{CuFeS}_{2}$ in $\mathrm{H}_{2} \mathrm{SO}_{4}-\mathrm{Fe}_{2}\left(\mathrm{SO}_{4}\right)_{3}-\mathrm{FeSO}_{4}-\mathrm{H}_{2} \mathrm{O}$ system (2) to observe the formation and evolution of intermediates phases during $\mathrm{CuFeS}_{2}$ leaching (3) to carry out a brief thermodynamic and kinetic investigation on the intermediate phase (4) identify the refractory transient phase at $50{ }^{\circ} \mathrm{C}$ and media $\mathrm{pH}$ of 1.8 .

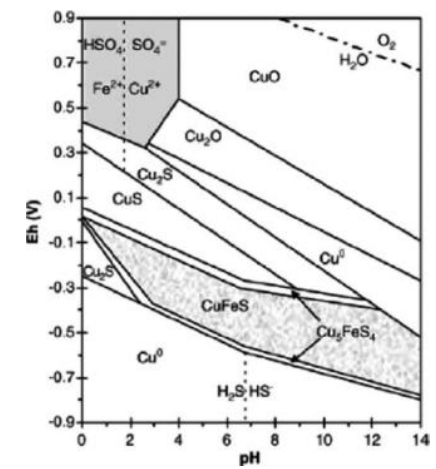

Fig. 1: potential $-\mathrm{pH}$ diagram $\mathrm{Cu}-\mathrm{Fe}-\mathrm{S}-\mathrm{H} 2 \mathrm{O}$ at $250^{\circ} \mathrm{C}$

\section{MATERIALS AND METHODS}

\section{A. Materials}

Solutions of the desired $\mathrm{pH}$ were prepared using analytical reagent-grade sulphuric acid $\left(\mathrm{H}_{2} \mathrm{SO}_{4} 98 \% \mathrm{ACE}\right)$, ferric sulphate $\left(\mathrm{Fe}_{3}\left(\mathrm{SO}_{4}\right) \cdot \mathrm{H}_{2} \mathrm{O} A C E\right)$, and deionized water $(<5.0 \mu \mathrm{s} / \mathrm{cm})$. The measured redox potential $(\mathrm{Ag} / \mathrm{AgCl})$ measurements were referenced to the Standard Hydrogen Electrode (SHE).

\section{B. Chalcopyrite sample}

$\mathrm{CuFeS}_{2}$ sample originated from a Limpopo province, (Phalaborwa South Africa). The received samples were dried in an oven at 50 degrees Celsius $\left({ }^{\circ} \mathrm{C}\right)$ for seven days. Laboratory sub-sampling and homogenization were conducted according to the soil sampling protocol published by the US Environmental Protection Agency [22].

Figures 2 summarizes the sample mineral, the XRD patterns further indicated a high purity and well crystallized $\mathrm{CuFeS}_{2}$ (70\%) accompanied by $\mathrm{Mg}\left(\mathrm{CaCO}_{3}\right)(24.3 \%)$ and with a very small amount of $\mathrm{SiO}_{2}(4.09 \%)$ and $\mathrm{Fe}_{2} \mathrm{O}_{3}(1.58 \%)$. A grain size of $-38+20 \mu \mathrm{m}$ was used as a dissolution feed.

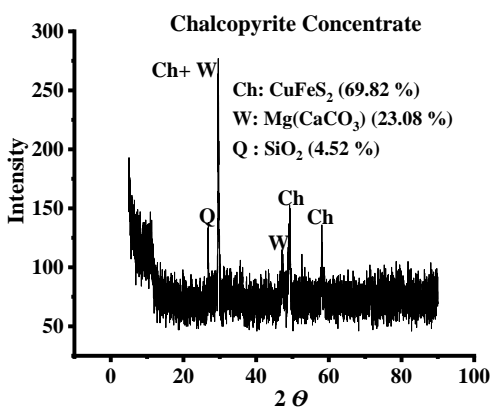

Fig. 2: $\mathrm{CuFeS} 2$ sample mineral characterization

\section{Leaching test}

$\mathrm{CuFeS}_{2}$ dissolution was conducted in acidified ferric sulphate solution $\left(\mathrm{H}_{2} \mathrm{SO}_{4}-\mathrm{Fe}_{2}\left(\mathrm{SO}_{4}\right)_{3}\right)$, obtained by mixing $\mathrm{Fe}_{2}\left(\mathrm{SO}_{4}\right)_{3}$ with $\mathrm{H}_{2} \mathrm{O}$ water and $\mathrm{H}_{2} \mathrm{SO}_{4}$. An initial $\mathrm{Fe}$ content $\left(\mathrm{Fe}^{3+}=0.05 \mathrm{MFe}\right)$ was used for all tests. The media was agitated for 12 hours prior to use. Dissolution tests were performed in at atmospheric conditions at $50^{\circ} \mathrm{C}$ the media $\mathrm{pH}$ was measured and maintained at 1.8 with periodic addition of $\mathrm{H}_{2} \mathrm{SO}_{4}(98 \%)$ while the solution ORP was allowed to evolve throughout the dissolution test and was periodically (10 minutes) recorded.

The redox potential of the leaching solution was measured with a platinum electrode using a saturated $\mathrm{Ag} / \mathrm{AgCl}(3 \mathrm{M} \mathrm{KCl})$ electrode as the reference.

Solid leached residues were analyzed for mineral composition using XRD analysis (Rigaku Ultima IV) operating at $40 \mathrm{kV}$ and $30 \mathrm{~mA}$ and PDXL analysis software was used; the instrument's detection limit was $2 \%$. Data were recorded over the range $5^{\circ} \leq 2 \theta \leq 95^{\circ}$ at scan rate of $0.5^{\circ} / \mathrm{min}$ and a step width of $0.01^{\circ}$.

\section{RESULTS AND DISCUSSION}

\section{A. Dissolution curve and recovery}

Fig 4. shows the $\mathrm{Cu}$ dissolution recovery curve (a) and potential (ORP) evolution (b). Only $21 \% \mathrm{Cu}$ were dissolved for the pure concentrate $\left(\mathrm{CuFeS}_{2}\right)$. The dissolution curve was asymptotic and characterized by three stages: the first rapid (from 0 60 $\mathrm{min}$ ) than second (40 360 $\mathrm{min}$ ) and the third was the plateau with no $\mathrm{Cu}$ dissolution $(360 \sim 720 \mathrm{~min})$. It could suggest that the first rapid stage could be related to the $\mathrm{Cu}$ dissolution on the fresh surface while the second may be attributed to the leaching of intermediate phases if they are existent and the plateau stage could represent the passivation phenomenon whereby the undissolved $\mathrm{CuFeS}_{2}$ is completely enveloped by refractory material.

A sharp drop (Fig.3 (b)) in the solution potential (from 336.7 to $325.4 \mathrm{mV}$ ) was observed and could be due to the rapid consumption of ferric $\left(\mathrm{Fe}^{3+}\right)$ leading to $\mathrm{Cu}$ withdrawal and favoring the increase in $\mathrm{Fe}^{2+}$. 

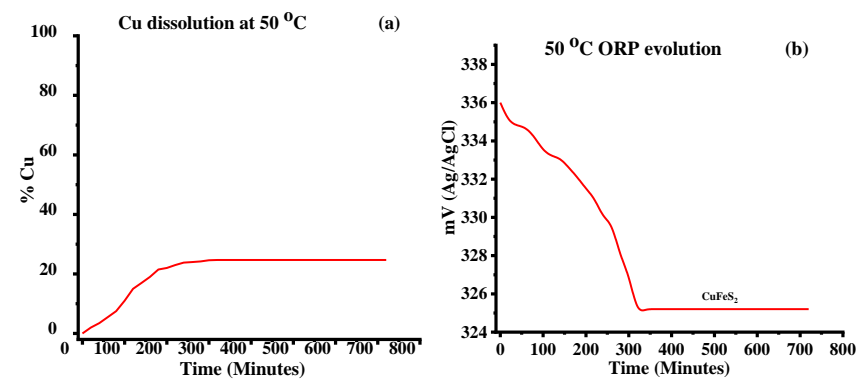

Fig. 3: $\mathrm{Cu}$ dissolution recovery and $\mathrm{Eh}(\mathrm{Ag} / \mathrm{AgCl})$ evolution

\section{B. Solid residue characterization}

Fig. 4 shows the solid residue characterization. The $\mathrm{CuFeS}_{2}$ main peaks ( $2 \theta=29.46,48.93$ and 57,95), appeared to have decreased in their intensity compared to the feed sample, suggesting a progressive $\mathrm{Cu}$ dissolution. In addition to that, $\mathrm{Cu}$ rich phase (bornite $(\mathrm{Bo})$, chalcocite $(\mathrm{Cx})$, and covellite $(\mathrm{Co})$ ) were observed. The presence of these $\mathrm{Cu}$-rich intermediates appeared to support earlier investigation by Acero, et al.,[23] which underlined the preferential dissolution of $\mathrm{Fe}$ over $\mathrm{Cu}$ leading to the formation of an Fe deficient chalcopyrite mineral (defect chalcopyrite structure $\mathrm{Cu}_{1-\mathrm{x}} \mathrm{Fe}_{1-\mathrm{y}} \mathrm{S}_{2-\mathrm{z}}$ ) to which our identified species could be part of.

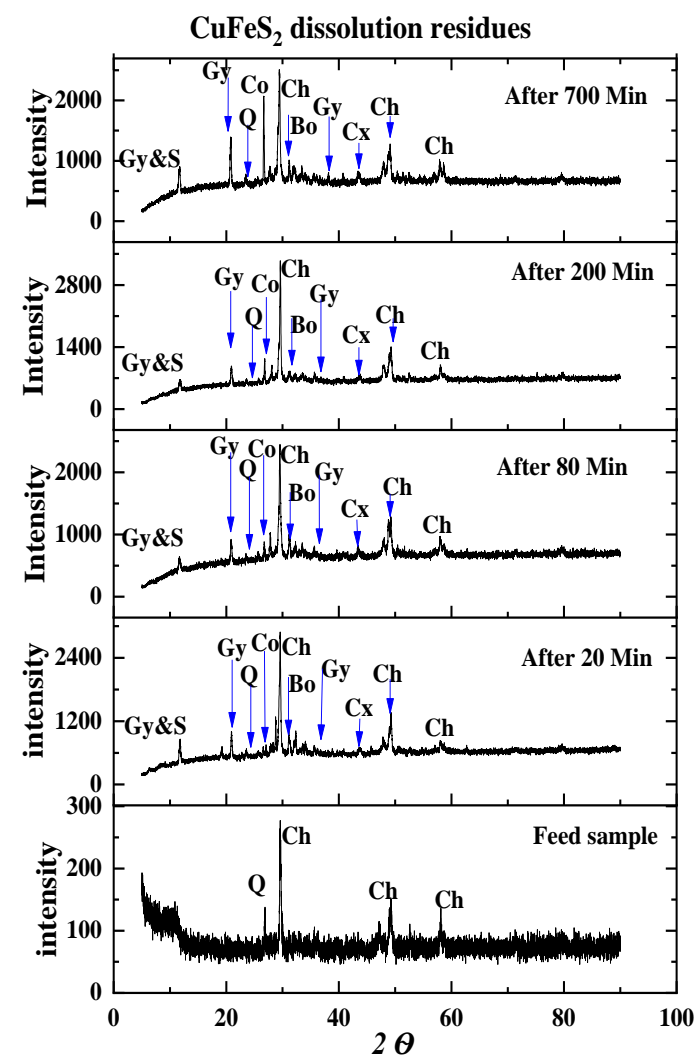

Fig. 4: mineral phase of solid leached residue

Sulphur (S), gypsum (Gy) and goethite (Go) and jarosite (Ja) were also identified in the leached residue. Sulphur must be a reaction product according to Equation $1(\mathrm{Eq}(1))$. Gypsum could be related to the carbonatite host rock. Goethite (Go) and jarosite would be formed through the hydrolysis of Fe during leaching.
Thermodynamically bornite is the most favorable phase to be formed $(\mathrm{Eq}(2))$, followed by chalcocite (Eq3) and, lastly, covellite (Eq4). These $\mathrm{Cu}-\mathrm{S}$ phases could further evolve into other phases (Eq(5) to (9)), or dissolve to promote Cu recovery (Eq(10) to (13)). $\mathrm{CuS}$ is likely to form from $\mathrm{Cu}_{5} \mathrm{FeS}_{4}(\mathrm{Eq} 7)$ than $\mathrm{Cu}_{2} \mathrm{~S}$ (Eq8). Similarly, Dutrizac et al. [24] and Zhao et al.[25] also ascribed the presence of $\mathrm{CuS}$ to a transient specie during the ferric leaching of $\mathrm{Cu}_{5} \mathrm{FeS}_{4}$. The intersection points between the various intermediates phases could suggest on one hand the dissolution competition between phases. While on the other hand, could also suggest the transformation from one phase into the other. In that sense, $\mathbf{I}_{\mathbf{1}}, \mathbf{I}_{\mathbf{2}}$ and $\mathbf{I}_{\mathbf{3}}$ observed between $\mathrm{CuS} / \mathrm{Cu}_{5} \mathrm{FeS}_{4}, \mathrm{CuS} / \mathrm{Cu}_{2} \mathrm{~S}$ and $\mathrm{CuS} / \mathrm{CuFeS}_{2}$ suggest the competition between the respective dissolution reactions and since $\mathrm{CuS}$ is refractory (Eq8), $\mathrm{Cu}_{5} \mathrm{FeS}_{4}, \mathrm{Cu}_{2} \mathrm{~S}$ and $\mathrm{CuFeS}_{2}$ dissolve by transformation into $\mathrm{CuS}$ according to $\mathrm{Eq} 7, \mathrm{Eq} 8$ and Eq9. This explains the increase in the $\mathrm{CuS}$ content and it cumulative behavior (Eq9) as observed in the XRD analysis. While I4 strictly represents the direct conversion of $\mathrm{CuFeS}_{2}$ to $\mathrm{Cu}_{2} \mathrm{~S}$ without any $\mathrm{Cu}^{2+}$ withdrawal according to Eq9.

$$
\begin{aligned}
& \mathrm{Eq}(5) \quad \mathrm{Cu}_{5} \mathrm{FeS}_{4}+2 \mathrm{Fe}_{2}\left(\mathrm{SO}_{4}\right)_{3} \rightleftharpoons 4 \mathrm{CuS}+5 \mathrm{FeSO}_{4}+\mathrm{CuSO}_{4} \\
& \Delta \mathrm{G}=-22.4 \mathrm{kCal}^{\mathrm{mol}}{ }^{-1} \\
& \mathrm{Eq}(6) \mathrm{Cu}_{2} \mathrm{~S}+\mathrm{Fe}_{2}\left(\mathrm{SO}_{4}\right)_{3} \rightleftharpoons \mathrm{CuS}+2 \mathrm{FeSO}_{4}+\mathrm{CuSO} 4 \\
& \Delta \mathrm{G}=-4.35 \mathrm{kCal}^{\mathrm{mol}}{ }^{-1} \\
& \mathrm{Eq}(7) \mathrm{CuFeS}_{2}+\mathrm{Fe}_{2}\left(\mathrm{SO}_{4}\right)_{3} \rightleftharpoons \mathrm{CuS}+3 \mathrm{FeSO}_{4}+\mathrm{S}^{\mathrm{o}} \\
& \Delta \mathrm{G}=-18.6 \mathrm{kCal}^{\mathrm{mol}}{ }^{-1} \\
& \mathrm{Eq}(8) \mathrm{CuS}+\mathrm{Fe}_{2}\left(\mathrm{SO}_{4}\right)_{3} \rightleftharpoons 2 \mathrm{FeSO} 4+\mathrm{S}^{\mathrm{o}}+\mathrm{CuSO}_{4} \\
& \Delta \mathrm{G}=+2.12 \mathrm{kCal} \mathrm{mol}^{-1} \\
& \mathrm{Eq}(9) \quad 2 \mathrm{CuFeS}_{2}+2 \mathrm{Fe}_{2}\left(\mathrm{SO}_{4}\right)_{3} \rightleftharpoons \mathrm{Cu}_{2} \mathrm{~S}+6 \mathrm{FeSO}_{4}+3 \mathrm{~S}^{\mathrm{o}} \\
& \Delta \mathrm{G}=-30.8 \mathrm{kCal} . \mathrm{mol}^{-1} \\
& \mathrm{Eq}(10) \mathrm{Cu}_{2} \mathrm{~S}+2 \mathrm{Fe} 2(\mathrm{SO} 4) 3 \rightleftharpoons 4 \mathrm{FeSO}_{4}+\mathrm{S}^{\mathrm{o}}+2 \mathrm{Cu}^{2+} \\
& \Delta \mathrm{G}=-2.25 \mathrm{kCal} \mathrm{mol}^{-1} \\
& \mathrm{Eq}(11) \mathrm{Cu}_{5} \mathrm{FeS}_{4}+6 \mathrm{Fe}_{2}\left(\mathrm{SO}_{4}\right)_{3} \rightleftharpoons 13 \mathrm{FeSO}_{4}+4 \mathrm{~S}^{\mathrm{o}}+5 \mathrm{Cu}^{2+} \\
& \Delta \mathrm{G}=-13.9 \mathrm{kCal} . \mathrm{mol}^{-1}
\end{aligned}
$$

\section{CONCLUSION}

This work investigated the dissolution of $\mathrm{CuFeS}_{2}$ in acidic $\mathrm{Fe}_{2}\left(\mathrm{SO}_{4}\right)_{3}$ at atmospheric conditions, $50^{\circ} \mathrm{C}$ and $\mathrm{pH}$ value of 1.8 . the results revealed a low copper dissolution due to the decrease in solution potential. However, it was observed that copper dissolution from chalcopyrite took place through solid state transformation by the formation of intermediates phases including $\mathrm{Cu}_{5} \mathrm{FeS}_{4}, \mathrm{Cu}_{2} \mathrm{~S}$ and $\mathrm{CuS}$. These intermediate phases were found to cause a retarding effect during $\mathrm{Cu}$ dissolution and hindered direct $\mathrm{CuFeS}_{2}$ oxidation. Thermodynamic predictions revealed that $\mathrm{Cu}_{5} \mathrm{FeS}_{4}$ and $\mathrm{Cu}_{2} \mathrm{~S}$ were the soluble intermediates and were characterized by a slow dissolution rate. Whereas, $\mathrm{CuS}$ has been identified as a refractory intermediate. The 
dissolution barrier could be a combination of Fe precipitates, covellite, and gypsum. Further investigation focusing on the control of redox potential should be considered to improve the $\mathrm{Cu}$ dissolution rate.

\section{ACKNOWLEDGMENT}

Author EFK acknowledged the financial support from the National Research Foundation (NRF) in South Africa (Grant No: 120323); Any opinion, findings and conclusions or recommendations expressed in this material are those of the authors and therefore the NRF does not accept any liability in regard thereto.

\section{REFERENCES}

[1]M. C. Ruiz, K. S. Montes, and R. Padilla, "Hydrometallurgy Chalcopyrite leaching in sulfate - chloride media at ambient pressure," Hydrometallurgy, vol. 109, no. 1-2, pp. 37-42, 2011. https://doi.org/10.1016/j.hydromet.2011.05.007

[2] S. Zhong and Y. Li, "An improved understanding of chalcopyrite leaching kinetics and mechanisms in the presence of NaCl," Integr. Med. Res., vol. 8, no. 4, pp. 3487-3494, 2019. https://doi.org/10.1016/j.jmrt.2019.06.020

[3]H. R. Watling, "Chalcopyrite hydrometallurgy at atmospheric pressure : 1 . Review of acidic sulfate, sulfate - chloride and sulfate - nitrate process options," Hydrometallurgy, vol. 140, pp. 163-180, 2013. https://doi.org/10.1016/j.hydromet.2013.09.013

[4]X. Xiong et al., "Oxidation mechanism of chalcopyrite revealed by X-ray photoelectron spectroscopy and first principles studies," Appl. Surf. Sci., vol. 427 , pp. 233-241, 2018. https://doi.org/10.1016/j.apsusc.2017.08.047

[5]Kolela J Nyembwe, Elvis Fosso-Kankeu, Frans Waanders, Kasongo D Nyembwe. 2019. Structural, compositional and mineralogical characterisation of carbonatitic copper sulfide concentrator plant streams: Run of mine, concentrate and tailings. International Journal of Minerals, Metallurgy and Materials. 26(2): 143-151. https://doi.org/10.1007/s12613-019-1718-8

[6]Kolela J Nyembwe, Elvis Fosso-Kankeu, Frans Wanders and Edward Ntumba Malenga. 2018. Mineralogical Observation Made During the Kinetic Dissolution Study of Chalcopyrite Mineral in Sulphate Media under Free pH at Room Temperature. Editors: Elvis Fosso-Kankeu, Frans Waansders, Michel Plaisent. 10th Int'l Conference on Advances in Science, Engineering, Technology \& Healthcare (ASETH-18) Nov. 19-20, 2018 Cape Town (South Africa). ISBN: 978-81-938365-2-1. Vol II. Pp 144-148.

[7]Brad Barlow, Elvis Fosso-Kankeu, Kolela J Nyembwe, Frans Waanders and Edward Ntumba Malenga. 2018. Prediction of Dissolution of Copper from a Chalcopyrite Carbonatite Ore of South Africa. Editors: Elvis Fosso-Kankeu, Frans Waansders, Michel Plaisent. 10th Int'l Conference on Advances in Science, Engineering, Technology \& Healthcare (ASETH-18) Nov. 19-20, 2018 Cape Town (South Africa). ISBN: 978-81-938365-2-1. Vol I. Pp 96-100.

[8]A. F. Tshilombo, "Mechanism and kinetics of chalcopyrite passivation and depassivation during ferric and microbial leaching," British Columbia, 2004.

[9]H. Naderi, M. Abdollahy, N. Mostoufi, M. J. Koleini, S. A. Shojaosadati, and Z. Manafi, "Kinetics of chemical leaching of chalcopyrite from low grade copper ore: Behavior of different size fractions," Int. J. Miner. Metall. Mater., vol. 18, no. 6, pp. 638-645, 2011. https://doi.org/10.1007/s12613-011-0489-7

[10] O. G. Olvera, M. Rebolledo, and E. Asselin, "Atmospheric ferric sulfate leaching of chalcopyrite: Thermodynamics, kinetics and electrochemistry," Hydrometallurgy, vol. 165, pp. 148-158, 2016. https://doi.org/10.1016/j.hydromet.2015.09.017

[11] C. Klauber, "A critical review of the surface chemistry of acidic ferric sulphate dissolution of chalcopyrite with regards to hindered dissolution,” Int. J. Miner. Process., vol. 86, pp. 1-17, 2008. https://doi.org/10.1016/j.minpro.2007.09.003

[12] S. M. J. Koleini, V. Aghazadeh, and Å. Sandström, "Acidic sulphate leaching of chalcopyrite concentrates in presence of pyrite," Miner. Eng., vol. 24, no. 5, pp. 381-386, 2011.

https://doi.org/10.1016/j.mineng.2010.11.008

[13] P. B. Munoz, J. D. Miller, and M. E. Wadsworth, "Reaction mechanism for the acid ferric sulfate leaching of chalcopyrite," Metall. Trans. B, vol. 10 , no. 2 , pp. $149-158,1979$. https://doi.org/10.1007/BF02652458

[14] J. E. Dutrizac, "The dissolution of chalcopyrite in ferric sulfate and ferric chloride media," Metall. Trans. B, vol. 12, no. 2, pp. 371-378, 1981. https://doi.org/10.1007/BF02654471

[15] T. Havlik and M. Skrobian, "Acid leaching of chalcopyrite in the presence of ozone," Can. Metall. Q., vol. 29, no. 2, pp. 133-139, 1990. https://doi.org/10.1179/cmq.1990.29.2.133

[16] C. Gómez, M. Figueroa, J. Muñoz, M. L. Blázquez, and A. Ballester, "Electrochemistry of chalcopyrite," Hydrometallurgy, vol. 43, no. 1-3, pp. 331-344, 1996 https://doi.org/10.1016/0304-386X(96)00010-2

[17] E. M. Córdoba, J. A. Muñoz, M. L. Blázquez, F. González, and A. Ballester, "Passivation of chalcopyrite during its chemical leaching with ferric ion at $68^{\circ}$ C," Miner. Eng., vol. 22, no. 3, pp. 229-235, 2009. https://doi.org/10.1016/j.mineng.2008.07.004

[18] E. M. Córdoba, J. A. Muñoz, M. L. Blázquez, F. González, and A. Ballester, "Leaching of chalcopyrite with ferric ion . Part IV : The role of redox potential in the presence of mesophilic and thermophilic bacteria," Hydrometallurgy, vol. 93, pp. 106-115, 2008. https://doi.org/10.1016/j.hydromet.2007.11.005

[19] G. Viramontes-gamboa, M. M. Peña-gomar, and D. G. Dixon, "Hydrometallurgy Electrochemical hysteresis and bistability in chalcopyrite passivation," Hydrometallurgy, vol. 105, no. 1-2, pp. $140-147,2010$ https://doi.org/10.1016/j.hydromet.2010.08.012

[20] A. Sandstrom, A. Shchukarev, and J. Paul, "XPS characterisation of chalcopyrite chemically and bio-leached at high and low redox potential," Miner. Eng., vol. 18, pp. 505-515, 2005. https://doi.org/10.1016/j.mineng.2004.08.004

[21] A. L. A. Santos, F. A. Arena, A. V. Benedetti, and D. Bevilaqua, "Effect of redox potential on chalcopyrite dissolution imposed by addition of ferrous ions," Eclet. Quim., vol. 42, no. 1, pp. 40-50, 2017. https://doi.org/10.26850/1678-4618eqj.v42.1.2017.p40-50

[22] K. Simons, "Soil Sampling," Geogia, 2014.

[23] P. Acero, P Cama, J Ayora, C Asta, M, "Chalcopyrite dissolution rate law from pH 1 to 3," Geol. Acta, vol. 7, no. 3, pp. 389-397, 2009.

[24] J. E. Dutrizac, T. T. Chen, and J. L. Jambor, "Mineralogical changes occurring during the ferric lon leaching of bornite," Metall. Trans. B, vol. 16 , no. 4, pp. 679-693, 1985 . https://doi.org/10.1007/BF02667505

[25] H. Zhao, J. Wang, W. Qin, M. Hu, and G. Qiu, "Electrochemical dissolution of chalcopyrite concentrates in stirred reactor in the presence of Acidithiobacillus ferrooxidans," Int. J. Electrochem. Sci., vol. 10, no. 1, pp. 848-858, 2015. 